\title{
Proteome analysis of muscadine grape leaves
}

\author{
This article was published in the following Dove Press journal: \\ International Journal of Wine Research \\ 28 April 2009 \\ Number of times this article has been viewed
}

\section{Sheikh M Basha' \\ Ramesh Katam' \\ Hemanth Vasanthaiah' Frank Matta ${ }^{2}$ \\ 'Center for Viticulture and Small Fruit Research, Florida $A$ and $M$ University, Tallahassee, FL, USA; ${ }^{2}$ Plant and Soil \\ Science Department, Mississippi State University, Mississippi State, MS, USA}

Correspondence: Mehboob B Sheikh 6505 Mahan Drive, Center for Viticulture and Small Fruit Research, Florida A\&M University, Tallahassee, FL 32317, USA

$\mathrm{Tel}+|850412519|$

Fax $+\mid 8505612617$

Email mehboob.sheikh@famu.edu
Abstract: Muscadine grapes are native to the southeastern United States and are used for making wine and consumed as fresh fruit. Grape berries, as 'sink organs,' rely on the use of available carbohydrate resources produced by photosynthesis to support their development and composition. A high throughput two-dimensional gel electrophoresis (2-DE) was conducted on muscadine (Vitis rotundifolia) grape leaf proteins to document complexity in their composition and to determine protein identity and function for enhancing photosynthetic efficiency of muscadine grape. 2-DE resolved muscadine leaf proteins into $>258$ polypeptides with pIs between 3.5 and 8.0 and molecular weight between 12,000 to 15,0000 Daltons. The consistently expressed proteins were excised and subjected to sequencing. Homology search of protein sequences showed $84 \%$ identity with Viridi plantae database. Identity of some of these proteins included RuBisCO, glutamine synthetase, pathogenesis-related protein, glyoxisomal malate dehydrogenase, ribonucleoprotein, chloroplast precursor, oxygen evolving enhancer protein. Comparative analysis of 10 muscadine cultivars showed quantitative differences in expression of 39 polypeptides among these genotypes. The results suggested that the polypeptide composition of muscadine grape leaf is complex, and polypeptide number and amount vary widely among muscadine genotypes, and these variations may be responsible for differences in their physiology, berry and stress tolerance characteristics.

Keywords: grapevine, leaves, muscadine, proteins, sequencing, 2-DE

\section{Introduction}

Grapevines are an important horticultural crop worldwide where they are cultivated for fruit, making wine and juice. In grape, efficient assimilation and use of nutrients by plant is of prime importance for the optimization of crop productivity and berry quality. Grape berries, as 'sink organs,' rely on the use of available carbohydrate resources produced by photosynthesis to support their growth and development. In grape, sucrose is the major form of carbohydrate loaded into the phloem at the leaves and distributed to sinks such as berry. The transport and allocation of sugars between the photosynthetic "source tissues" and the heterotrophic "sink tissues" is known as assimilate partitioning and is a major determinant of plant growth and productivity. ${ }^{1}$ Sucrose produced through photosynthesis in the mesophyll of mature leaves is the main carbohydrate used for long distance transport. ${ }^{2}$ Sucrose is loaded into the phloem by either a symplastic (via plasmodesmata) or apoplastic mechanism ${ }^{3}$ and as the major osmotically active constituent in the phloem it provides the driving force for translocating all other compounds in the phloem sap. ${ }^{3}$

Among the Vitis species, Vitis vinifera is cultivated worldwide and its development and physiology has been studied extensively. Muscadine (Vitis rotundifolia) grape is 
native to the southeastern United States and not well known outside the southern USA. They are also used for making wine, juice, jelly and eaten as fresh fruit. Bunch ( $V$. vinifera) grape contains significantly higher amount of sugars $(>24 \%)$ compared to muscadine berry $(14 \%-18 \%)$ and hence, the muscadine wine industry routinely adds sucrose to muscadine juice for promoting fermentation and increasing alcohol content of the wine. Muscadine grapes are tolerant to most diseases and have high nutraceutical value, and hence, have received serious attention by grape researchers as a unique genetic source for improving biotic and abiotic stress tolerance in bunch grape. Leaves are the main organ of photosynthesis and transpiration in higher plants and therefore, a large number of proteome studies have been concerned with various aspects of leaf development, genetics, and exposure of plants to a wide range of biotic and abiotic stresses. ${ }^{4-8}$ The progress made in the separation of proteins by two-dimensional gel electrophoresis (2-DE) coupled with the development of mass spectrometric technique has allowed powerful analysis of proteome changes and genetic differences. In most green leaf proteomes, ribulose bisphosphate decarboxylase/oxygenase is the most abundant protein, and can comprise more than half of the total leaf protein in some species. ${ }^{9}$ Several studies have analyzed the major soluble proteins present in leaves, and the two most extensive datasets to date were generated from 49-day-old rice leaves where 1022 proteins were identified ${ }^{10}$ and from Arabidopsis, where 1117 proteins were identified from 14-day-old primary leaves. ${ }^{11}$ In maize, 149 proteins were identified in the third leaf of 14-day-old seedlings. ${ }^{12}$ Proteome studies in wheat identified 142 proteins in 6- to 10 -day-old leaves ${ }^{13}$ and 55 proteins in 60-day-old leaves. ${ }^{14}$ A reference map of the pea leaf proteome has also been established which led to the identification of 130 leaf proteins at 4 to 24 days after planting and revealed a highly similar proteome map of stem and leaf proteins. ${ }^{15}$ This leaf proteome map was used to analyze quantitative variations in leaf proteins during nitrogen mobilization revealing that $40 \%$ of the proteins displayed significant changes in their abundance during leaf development. ${ }^{15}$

Vitis vinifera proteome has been studied extensively ${ }^{4,16-23}$ compared to muscadine proteome. Muscadine grapes have distinct morphology and significantly differ from Vitis vinifera in berry characteristics, composition and stress tolerance level. In view of the unique physiology and genetic make up of muscadine grape this study was focused on proteomics of muscadine leaf to increase our knowledge of muscadine leaf proteome and to infer their function in photosynthetic efficiency, berry composition, stress tolerance and plant defense by comparison with the proteins to which they are homologous. Here we report a detailed study on muscadine leaf proteins using a popular wine cultivar Carlos based on separation of leaf proteins by 2-DE and discuss their identity and function. In addition, we also compare protein profiles of selected muscadine genotypes (five wine and five table cultivars) to determine differences in their polypeptide profile, extent of genetic variation and their role in defining varietal characteristics.

\section{Materials and methods \\ Plant material}

Muscadine (Vitis rotundifolia) grape genotypes (10 cultivars) with diverse berry characteristics and usage (wine and table) grown at the Center for Viticulture and Small Fruit Research, Florida A and M University, Tallahassee, FL were used in this study. They are being maintained following recommended cultural practices for muscadine grape and received irrigation, pest control and fertilizers as per the recommended guidelines and were not exposed to any adverse environmental conditions. Fully expanded mature leaves were collected from selected grape genotypes in the morning hours (between 9:00 to 9:30 AM) in spring and transported to the lab on ice for further processing. To randomize biological variations, 50 leaves were collected from four to five plants of the same cultivar, pooled, washed, and quickly dried with paper towel. Leaves were then frozen in liquid nitrogen and stored at $-80{ }^{\circ} \mathrm{C}$ prior to protein extraction.

\section{Protein extraction and determination}

Leaf tissue was ground into a powder under liquid nitrogen, and one $\mathrm{g}$ of powder was suspended in $5 \mathrm{ml}$ solution of $70 \%$ acetone containing 20\% TCA and homogenized for $2 \mathrm{~min}$ on ice. The homogenate was centrifuged $\left(20000 \mathrm{~g}\right.$ at $4{ }^{\circ} \mathrm{C}$ for $15 \mathrm{~min}$ ) and the resulting pellet was washed three times with ethanol and then acetone. Protein was extracted from the acetone powder $(30 \mathrm{mg}$ ) using $500 \mu \mathrm{l}$ of lysis buffer (7 M urea, 2\% CHAPS [w/v], 2 M thiourea, 0.2\% DTT [w/v]) and insoluble material was removed by centrifugation. An aliquot of the supernatant was used for protein determination using the Bradford method, ${ }^{24}$ and the remaining sample was used for 2-DE. This protein extraction protocol was found to yield maximum amount of good quality protein suitable for 2-DE.

\section{Two-dimensional gel electrophoresis (2-DE)}

An aliquot $(100 \mu \mathrm{g})$ of the protein extract was loaded on to gels and isoelectric focusing (IEF) was performed following the method of Basha ${ }^{25}$ using $\mathrm{pH} 3.5$ (50\%), $\mathrm{pH} 8.5$ 
to $10(14 \%)$ and pH 5-7 (26\%) ampholines (Sigma Chemicals, St. Louis, MO). After IEF, the gels were equilibrated for $15 \mathrm{~min}$ in equilibration buffer (50 mM Tris- $\mathrm{HCl}, \mathrm{pH} 8.8$; $6 \mathrm{M}$ urea; $30 \%$ [v/v] glycerol; $2 \mathrm{M}$ thiourea; $\%$ [w/v] SDS; and $2 \%[\mathrm{w} / \mathrm{v}]$ DTT). Second-dimension was run in $13 \%(\mathrm{w} / \mathrm{v})$ acrylamide slab gels at $18{ }^{\circ} \mathrm{C}$ in a Tris-Gly buffer $(25 \mathrm{mM}$ Tris-HCl; 192 mM glycine; 0.1\% [w/v] SDS) system. Running conditions were $20 \mathrm{~min}$ at $20 \mathrm{~mA} / \mathrm{gel}$, and $2 \mathrm{~h}$ at 40 $\mathrm{mA} /$ gel until the tracking dye reached the bottom of the gel. These conditions allowed separation of polypeptides with a molecular mass ranging from 12 to $150 \mathrm{kDa}$. The 2-DE gels were stained with Coomassie Brilliant Blue R-250 to visualize protein spots. Protein standards (Sigma) with known molecular weight and isoelectric point $(\mathrm{pI})$ were used to calibrate the gel and obtain experimental molecular weight and $\mathrm{pI}$ of the protein spots. Each sample was run in replicates of three or more to obtain a consistent protein profile.

The above described protein extraction and 2-DE protocol was found to be optimum for the separation of muscadine leaf proteins and hence, used for characterization of all the muscadine genotypes.

\section{Gel image analysis}

Images of three replicate gels were taken by Proteome Works Spot Cutter (BioRad Laboratories, Hercules, CA) and analyzed by PD Quest software, version 7.2 (BioRad). To reduce background noise and eliminate unexploitable spots, a maximal area common to all gels within a cultivar was defined using selected major proteins bordering each side of the gels. In all cases this area corresponded to at least $95 \%$ of the total gel. Three independent replicates were performed for each of the 10 genotypes studied and image analysis was carried out considering all the gels. Classic Match tool which utilizes landmarks was employed to match protein spots that were consistently present in the same position in all the three gel replicates. From this match, an Analysis Set was created which served as a "pick-list" for spot excision, in-gel trypsin digestion, and protein identification by mass spectrometry. Spots were robotically excised from 2-D gels by Proteome Works Spot Cutter (BioRad). In-gel trypsin digestion was performed using the ProPrep (Genomic Solutions, Ann Arbor, MI) robotic digester/spotter, applying a method published previously. ${ }^{26}$ Mass spectra were collected on ABI 4700 Proteomics Analyzer (Applied Biosystems, Foster City, CA) MALDI TOF-TOF mass spectrometer (MS) and protein identification (ID) was performed using the automated resultdependent analysis (RDA) of ABI GPS Explorer software, version 3.5 (Applied Biosystems).

\section{Protein identification by mass spectrometry analysis}

The initial MS scan obtained the $\mathrm{m} / \mathrm{z}$ values for preliminary ID based on peptide mass fingerprinting (PMF). Proteins with high confidence ID (cross confidence interval [CI]\%>95\%) were automatically subjected to "in silico" trypsin digestion, and their five most prevalent corresponding peptides-precursor ions present in the MS spectra were selected for MS/MS analysis called RDA_1 (top protein confirmation). Both MS and MS/MS data were matched against the National Center for Biotechnology Information (NCBI) Vitis spp. and Viridi plantae taxonomic databases (as of January 2009) using the MASCOT (Matrix Science, Boston, MA) algorithm. ${ }^{27}$ The samples that failed to provide high confidence ID after the combined search were characterized by de novo sequencing (module of the ABI GPS software) of their corresponding spectra. De novo obtained amino acid sequences were automatically BLAST ${ }^{28}$ against the NCBI Viridi plantae database (as of January 2009). Only the "positive hit" (according to the BLAST algorithm) was considered as an indication of sequence homology with the particular database entry.

\section{Results}

\section{Muscadine leaf protein composition}

The low abundance of proteins along with pigments, lipids and phenolics associated with grape leaves is the major challenge for 2-DE. Different chaotropes, detergents and ampholine combinations were tested to enhance the solubility and resolution of leaf proteins, and minimize interference from various leaf metabolites. The solubilization efficiency depends not only on the nature of leaf proteins, but also on the leaf morphology, lipid and pigment content, and the sample preparation prior to final solubilization. Further, unlike the methods that use strips in IEF dimension, it was found that alkylation prior to reduction is not necessary because it had no effect on protein resolution in our acrylamide-based method. ${ }^{25}$ Initially, several $(>10)$ muscadine cultivars were evaluated using the optimized protein extraction and 2-DE protocols described above in Methods. Based on this evaluation cv. Carlos was chosen for detailed protein characterization because it contained majority of the proteins found in muscadine cultivars, and is one of the popular wine cultivar grown in southeastern USA. The 2-DE analysis of Carlos leaf proteins showed a total of 258 proteins across the three replicate gels in a highly reproducible manner (Figure 1). The 2-DE profile showed that leaf proteins were resolved in to a diverse category of polypeptides with molecular weight $\left(\mathrm{M}_{\mathrm{r}}\right)$ 
ranging between 12,000 and 150,000 Da and the pI between 3.5 and 8.0. The majority of the proteins were found to be in the $90,60,40$, and $25 \mathrm{kDa}$ range with pI between 4.5 and 7.5. Interestingly, some of the leaf proteins with apparent $\mathrm{M}_{\mathrm{r}}>50 \mathrm{kDa}$ resolved into clusters of multiple spots. The apparent $\mathrm{M}_{\mathrm{r}}$ of proteins in each cluster was similar but their pIs were slightly different resulting in series of spots. Most of these clusters focused between $\mathrm{pH} 4.5$ to 7.5 and had $\mathrm{M}_{\mathrm{r}}$ between 50 and $75 \mathrm{kDa}$. Such polypeptide clusters have been observed on 2-DE of several seed, leaf and microbial protein extracts and appears to be of normal occurrence in plant tissue. ${ }^{25,29-31}$

\section{Identification of protein spots}

Protein spots were detected on the gel as described in the Methods, robotically excised from the gel and trypsin digested. The digested samples were subjected to LC-MS/MS analysis to obtain peptide sequences. Out of 258 protein spots resolved on the gel, 217 protein spots were successfully identified by MASCOT database search. In addition, a MOWSE score was obtained from MASCOT, which rates scores as significant if they are above the $95 \%$ significance threshold $(\mathrm{p}<0.05){ }^{32,33}$ The resulting data were matched against the NCBI Vitis and Viridi plantae taxonomic databases. Identity and function of some of the abundant and most commonly found proteins are shown in Table 1. They include chloroplast heat shock protein, ATPases, RuBisCO activase, ribulose 1, 5-bisphosphate carboxylase/oxygenase ( $\mathrm{RuBisCO}$ ), glutamine synthetase, glyceraldehyde 3-phosphate dehydrogenase, pathogenesisrelated protein and several unknown proteins which have no match with proteins of Vitis taxa in the NCBI database. The unknown proteins were BLAST with other taxa in the NCBI database to determine their identity and function. However, a few of them did not match with any known proteins of any taxa. It is also noted that some of the proteins were resolved into multiple spots with varying $\mathrm{M}_{\mathrm{r}}$ and $\mathrm{pI}$ suggesting that these proteins exist in multiple subunits. For example,

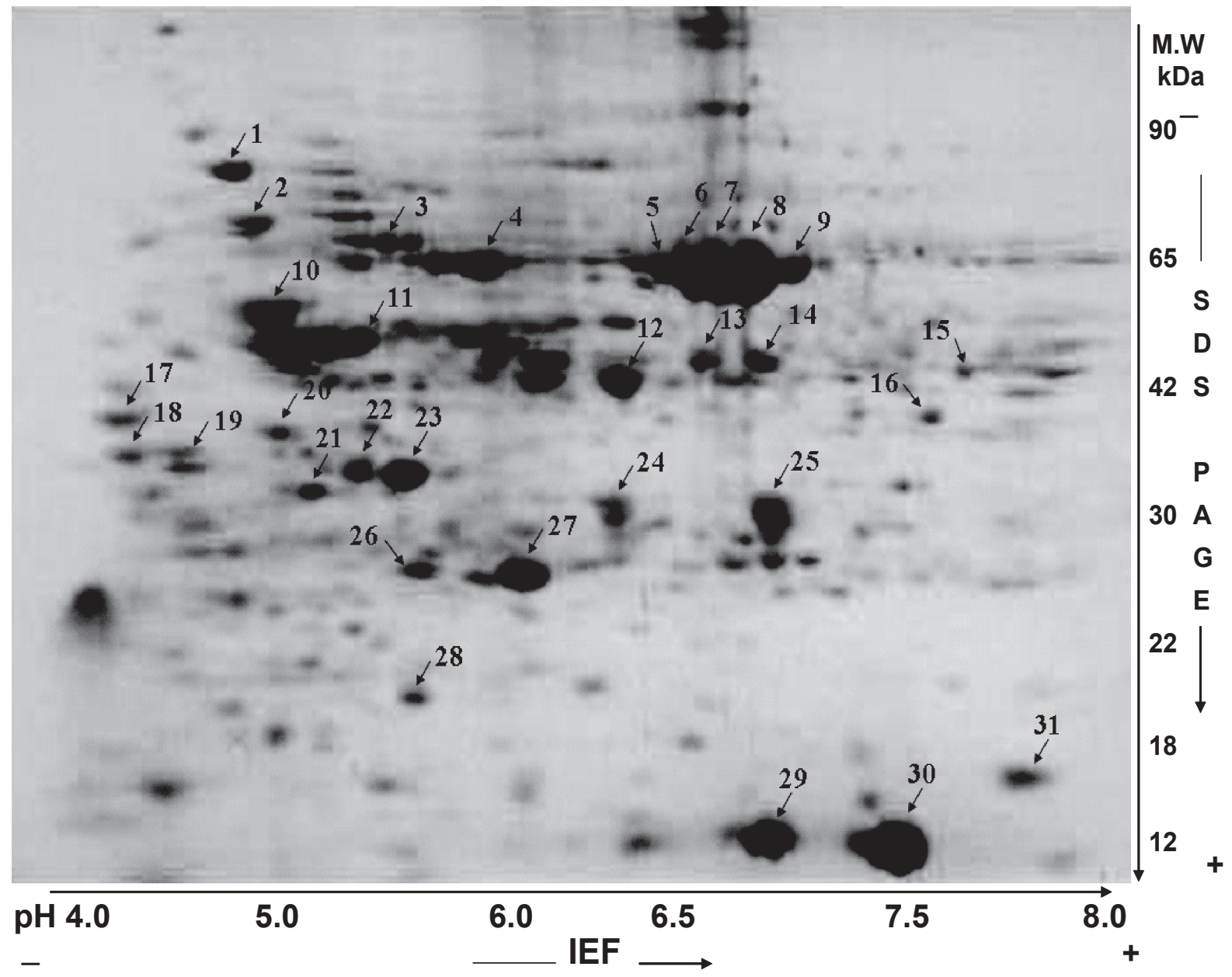

Figure I Two-dimensional gel electrophoresis profile of muscadine leaf proteins from cv. Carlos. 
RuBisCO small subunits were distributed in three different regions of the gel with pI values of 5.7, 6.7, and 7.3 and molecular weights 23,13 , and $12.8 \mathrm{kDa}$, respectively. These polypeptides showed $100 \%$ homology with RuBisCO small subunit of Vitis rotundifolia in Vitis database (Table 1). In addition, ATP synthase beta subunit, RuBisCO large subunit and oxygen evolving enhancer protein also were found to exist in multiple subunits (Table 1).

\section{Functional classification of muscadine leaf proteins}

All the identified polypeptides (217) were grouped into seven categories according to their function as per the annotation in the Viridi plantae and Vitis taxonomic databases (Figure 2). Functional classification of identified proteins showed them to be associated with transport (18\%), metabolism (19\%), signal transduction ( $8 \%$ ), energy (15\%), cellular biogenesis (4\%) and protein synthesis (12\%). About 24\% (52 of 217 polypeptides) of the proteins were grouped into unknown function category because they did not make a BLAST.

\section{Variation in leaf protein composition among muscadine genotypes}

Leaves from selected popular muscadine cultivars were examined to illustrate extent of genetic variation in protein composition among the genotypes. Leaf polypeptide profiles of selected muscadine cultivars are shown in Figure 3. They included both the wine (Magnolia, Noble) and table (African Queen, Higgins) fruit types. Variation in leaf protein composition among muscadine cultivars was determined by comparing their 2-DE profiles both manually and using PD Quest 2-D Analysis Software (BioRad). These data revealed (Figure 3 ) that the number of polypeptides varied greatly among the muscadine cultivars. Thus the cultivars Magnolia, African Queen, Noble and Higgins showed 188, 238, 257 and 281 protein spots, respectively. The polypeptide profile also revealed that most of the polypeptides were present in all the muscadine cultivars studied but significant $(\mathrm{P}>0.05 \%)$ differences exist in their abundance among the genotypes. Based on the comparative analysis of these cultivars using PD Quest software (BioRad), 39 proteins showing major quantitative differences were identified. In each data set, three gel images from replicated samples were used to create a master gel. After normalizing the gels, scatter plot was obtained (PD Quest). Analysis sets were created using PD Quest software and used to determine quantitative and qualitative differences in proteins of interest. The spot detection parameters were optimized based on the sensitivity, size scale and minimum peak area. The polypeptides which show distinct quantitative differences among the genotypes are denoted into 12 regions (Blocks A to L, Figure 3) based on their position on the 2-DE gel.

A close up view of these 12 regions (Blocks A through L, Figure 3) is shown in Figure 4. For ease of identification polypeptides within each block are numerically labeled. Comparison of polypeptides in block A showed that Magnolia, African Queen and Higgins contained three polypeptides (1, 2 and 3) while Noble contained reduced levels of polypeptides 2 and 3, and lacked polypeptide 1 . In block D, polypeptides 1 and 2 were present in Magnolia and African Queen while they were found only in trace amount in Noble and Higgins. In addition, the amount of polypeptides 3, 4 and 5 were lower in Noble compared to other three cultivars. In block I, Higgins and Noble contained higher amounts of polypeptides 1, 2 and 3 while Magnolia and African Queen contained reduced levels of these peptides. Similar differences in polypeptide number and protein intensity was found in blocks B, C, E, F, G, H, J, K and L (Figure 4). These data demonstrated that major differences exist in polypeptide number and their quantity among muscadine genotypes.

The identity of 39 differentially expressed proteins (Figures 3 and 4) among the muscadine genotypes is shown in Table 2. The proteins include aspartate aminotransferase, hydroxypyruvate reductase, fructose 1,6, bisphosphate aldolase, superoxide dismutase, RuBisCO large subunit, triose phosphate isomerase, etc. In addition, eight polypeptides were identified as unknown, since they did not make a BLAST with Vitis or other databases. Based on the homology search we have determined that multiple forms of hydroxypyruvate reductase, fructose 1,6, bisphosphate, aldolase, Os12 g, peroxiredoxin, RuBisCO large subunit, and elongation factor $\mathrm{G}$ are distributed across the 2-DE gel. It is noteworthy that the amount of these proteins greatly varied among the cultivars studied. One of the fructose 1, 6 , bisphosphate aldolase polypeptide (B-1) was significantly lower in Noble compared to other cultivars (Figure 4). Similarly, several other proteins also showed significant quantitative differences among the cultivars. It was interesting to note that homology of certain polypeptides was very high ( $>99 \%$ ) while in others the polypeptide score and organism varied widely. For example, elongation factor G (L1 and L2 Figure 4) showed similar hits to Glycine max with similar peptide match and MASCOT score while peroxiredoxin showed hits with two different organisms (Populus tremula 


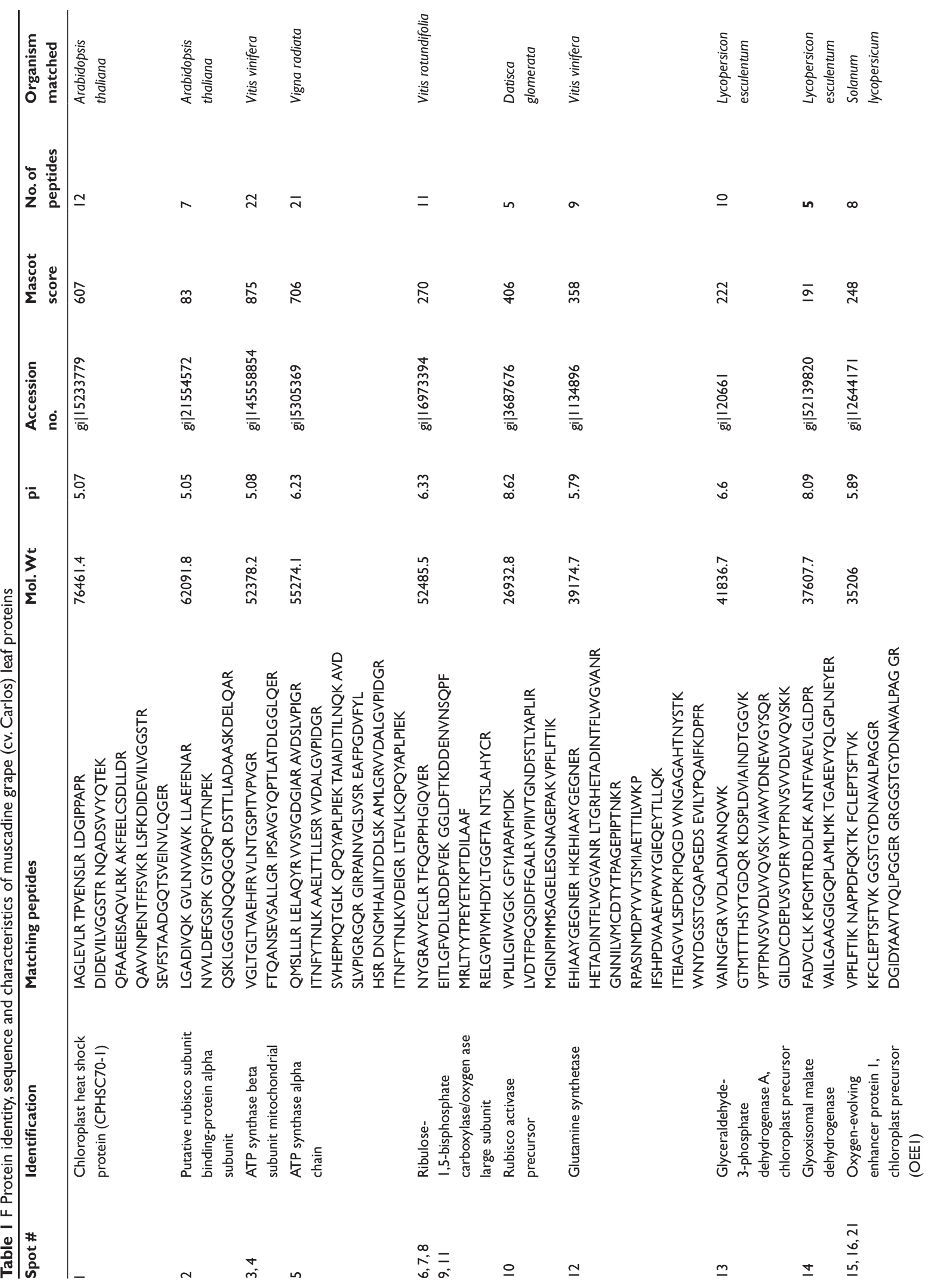




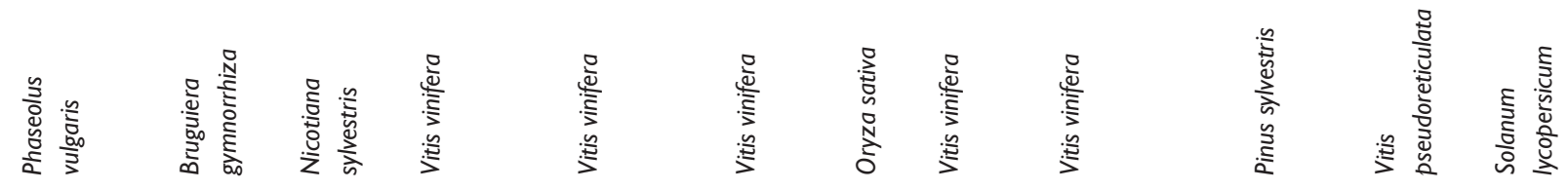

$\simeq \quad=m$

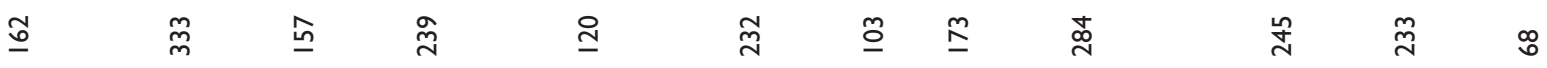

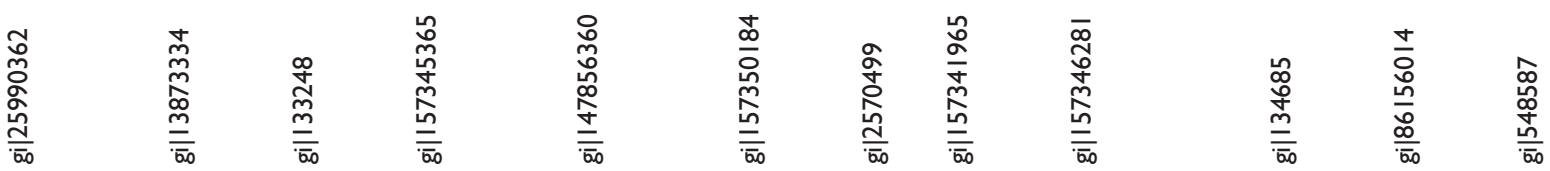

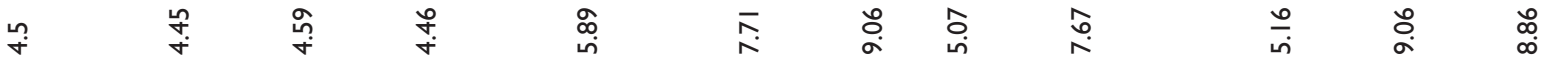

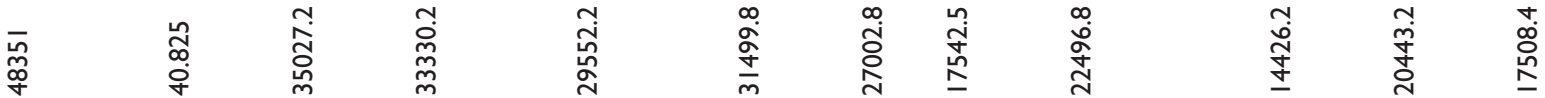
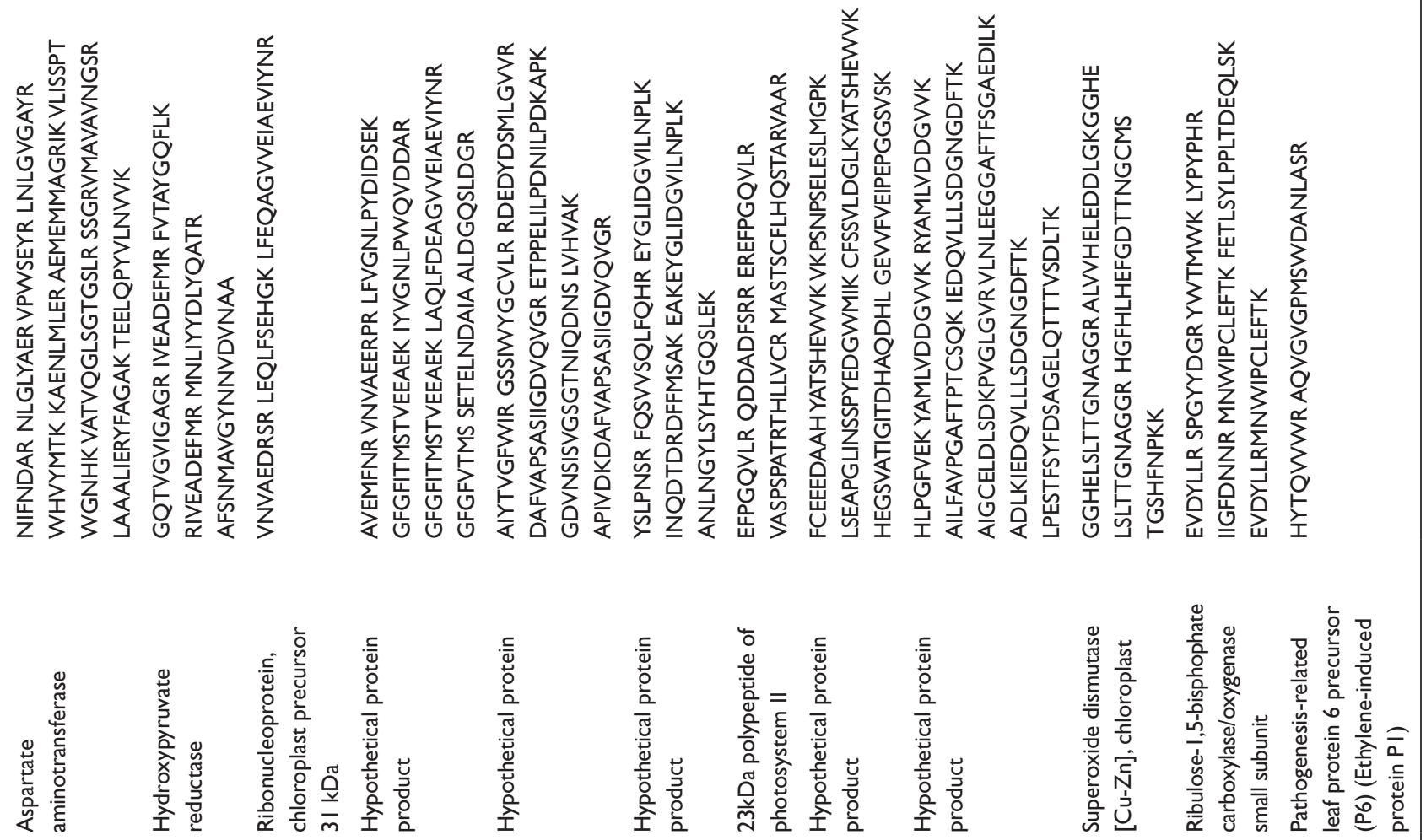

$\triangle$

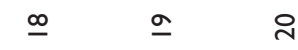

ส

ก

$\stackrel{4}{\sim} \stackrel{4}{4}$

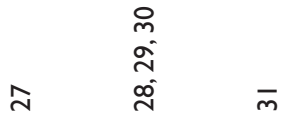




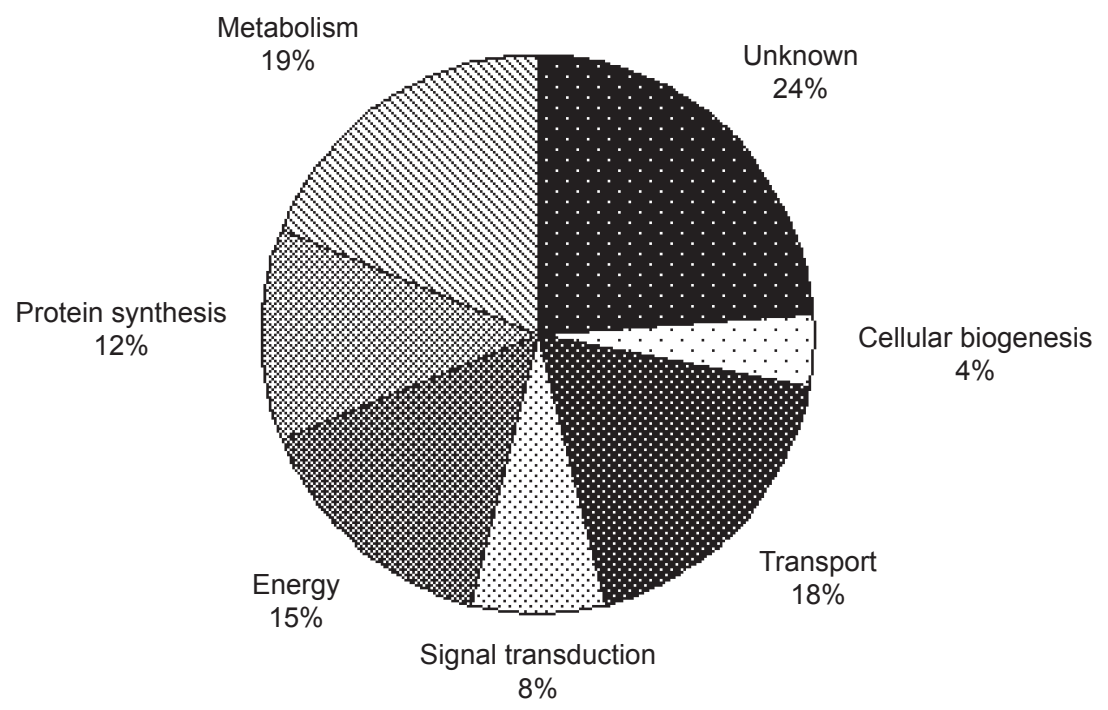

Figure 2 Distribution of muscadine leaf proteins based on their function.

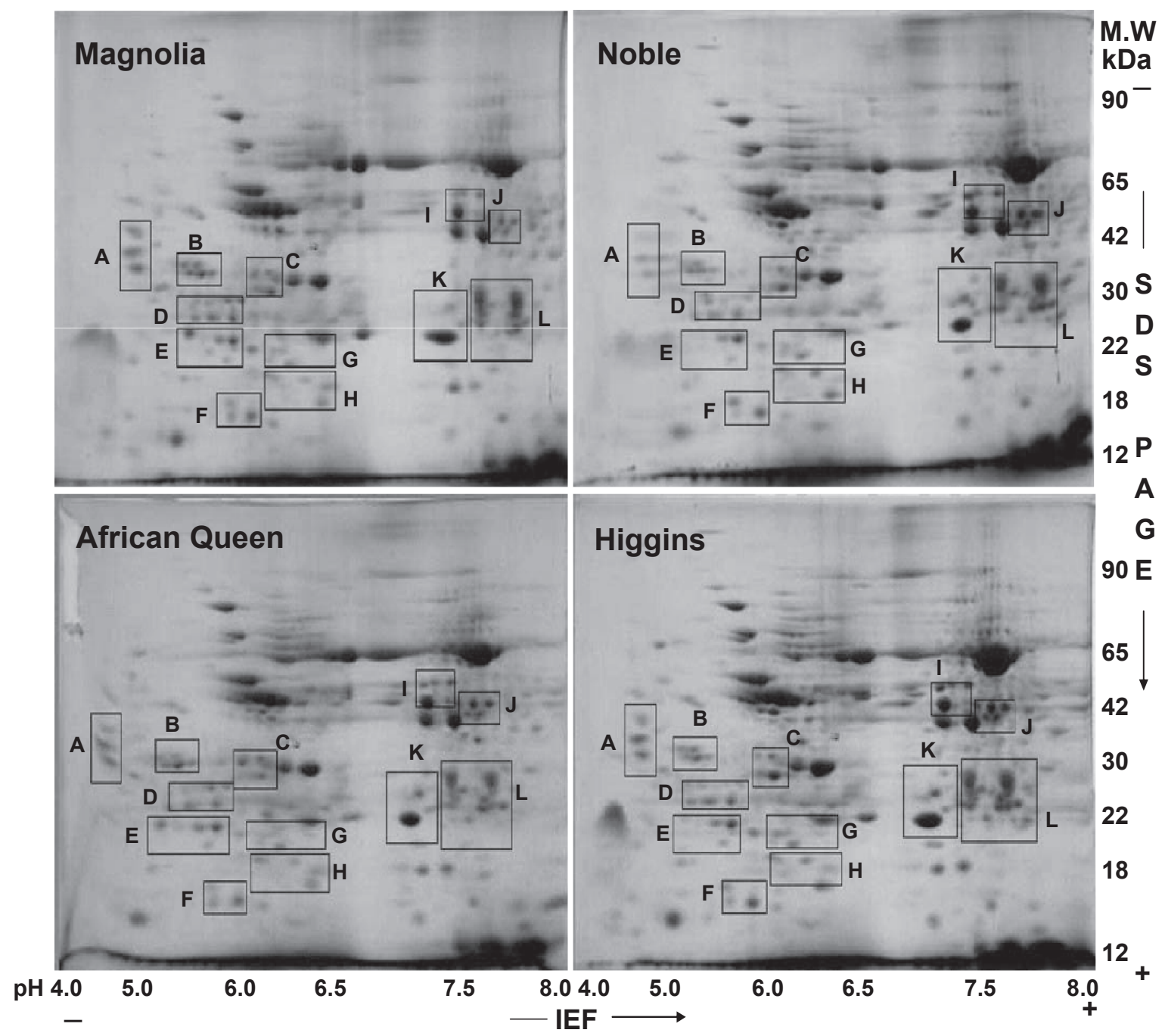

Figure 3 Variation in leaf protein composition among muscadine cultivars. Proteins showing major quantitative differences are enclosed in blocks A to L. 

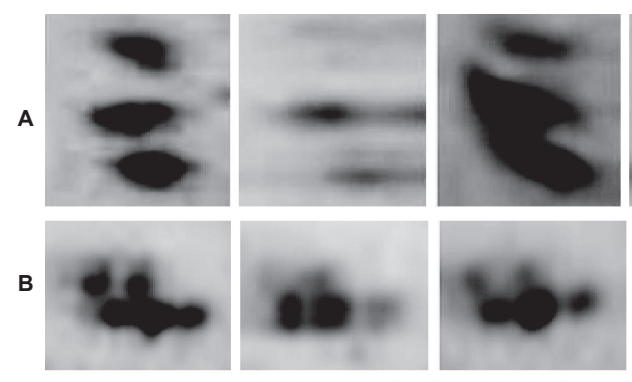

C
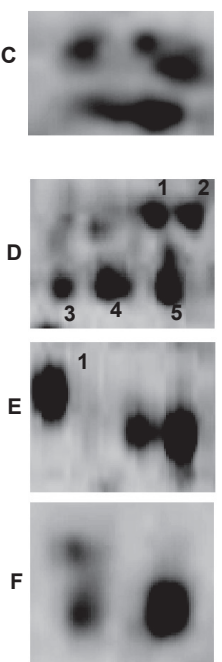

I
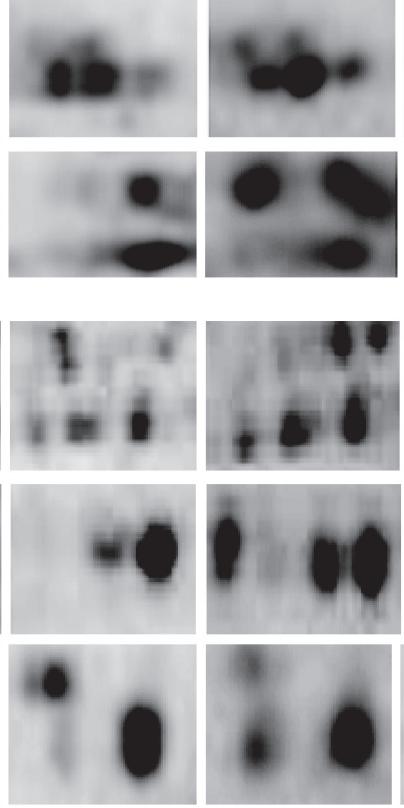

II
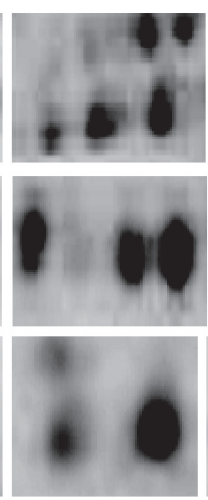

III
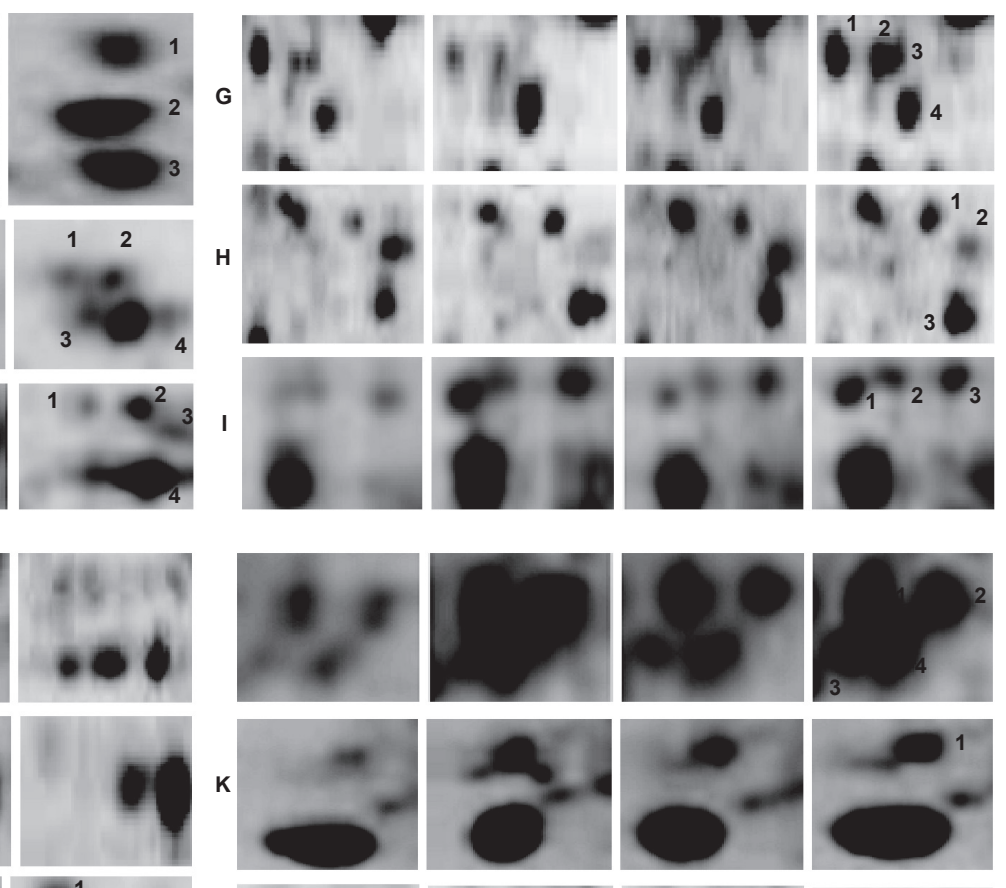
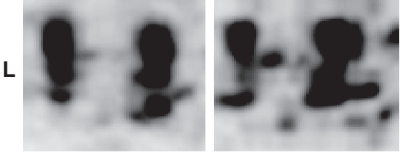

II

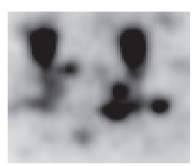

III

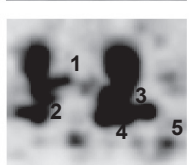

IV
I

Figure 4 A close up view of two-dimensional gel electrophoresis (2-DE) gel regions showing differences in polypeptide composition among muscadine cultivars (I: Magnolia, II: Noble, III:African Queen, IV: Higgins). For ease of identification polypeptides within each block are numerically labeled. Positions of these blocks on 2-DE gel are shown in Figure 3.

and Phaseolus vulgaris), different MASCOT score and peptide match (Table 2) indicating genetic diversity in these proteins among the taxa.

\section{Discussion}

This is the first proteomic study on muscadine leaf which dealt with determining its proteome profile, functionality and genetic diversity. Muscadine leaf proteome was found to be complex and contained more than 258 (217 matched and 41 unmatched) proteins which are significantly higher than grape berry. They appear to be involved in metabolism, transport, energy, protein synthesis, signal transduction, and cellular biogenesis functions. In addition, a major portion (52 proteins or $24 \%$ of the matched proteins) of these proteins did not make a BLAST and needs further examination. The proteins found in muscadine leaf viz. chloroplast heat shock protein, ATPases, RuBisCO activase, ribulose 1,5-bisphosphate carboxylase/oxygenase (RuBisCO), glutamine synthetase, glyceraldehyde 3-phosphate dehydrogenase, pathogenesis-related protein, and several unknown proteins have been reported as true proteins in different plant species including Vitis which provides sound evidence on the quality of data presented in this report. Functional classification of the identified leaf proteins indicated them to be involved in metabolic and cellular processes, and demonstrated that leaf is a vigorous system in signal transduction and transportation of metabolites; dynamic for energy metabolism, protein trafficking, and proteolysis.

Most of the abundant proteins appear to be widely distributed among muscadine genotypes. For example, chloroplast heat shock protein 70 (also known as stress 70 molecular chaperones) has been found in most organisms from archaebacteria to eukaryotes and represent one of the most conserved protein families known to date. ${ }^{34} \mathrm{HSP} 70$ s are involved in almost every step of protein biogenesis. ${ }^{35}$ These proteins are located in the cytosol as well as in specific sub cellular compartments to bind unfolded polypeptides and to release them in an ATP-dependent reaction. ${ }^{36}$ Another group of proteins present in muscadine leaf are ATPases, which are membrane-bound enzyme complexes and ion transporters 
Table 2 Identitiy and characteristics of differentially expressed proteins in selected muscadine cultivars

\begin{tabular}{|c|c|c|c|c|c|}
\hline Spot \# & Protein name & Taxonomy & $\begin{array}{l}\text { Mascot scorel } \\
\text { peptides matched }\end{array}$ & $\begin{array}{l}\text { Theoretical } \\
\text { mass }(k D a) / p l\end{array}$ & $\begin{array}{l}\text { Accession } \\
\text { number }\end{array}$ \\
\hline \multicolumn{6}{|l|}{ Block A } \\
\hline 1 & Aspartate aminotransferase & Phaseolus vulgaris & $162 / 12$ & $48.3 / 4.5$ & gi|25990362 \\
\hline 2 & Hydroxypyruvate reductase & Bruguiera gymnorrhiza & $333 / 11$ & $40.8 / 4.45$ & gi|| 3873334 \\
\hline 3 & Hydroxypyruvate reductase & Bruguiera gymnorrhiza & $333 / 11$ & $40.8 / 4.45$ & gi|| 3873334 \\
\hline \multicolumn{6}{|l|}{ Block B } \\
\hline 1 & $\begin{array}{l}\text { Fructose } 1,6, \text { bisphosphate } \\
\text { aldolase }\end{array}$ & Salicornia herbacea & $66 / 4$ & $40.3 / 5.2$ & gi|40362980 \\
\hline 2 & $\begin{array}{l}\text { Fructose I,6, bisphosphate } \\
\text { aldolase }\end{array}$ & Salicornia herbacea & $66 / 4$ & $40.3 / 5.2$ & gi|40362980 \\
\hline 3 & Os I 2g0632700 & Oryza sativa (japonica) & $43 / 16$ & $39.4 / 5.5$ & gi||II54897I8 \\
\hline 4 & OsI2g063270I & Oryza sativa (japonica) & $44 / 16$ & $39.4 / 5.5$ & gi| I I54897/8 \\
\hline \multicolumn{6}{|c|}{ Block C } \\
\hline 1 & Hypothetical protein & Vitis vinifera & $191 / 24$ & $38.0 / 6.2$ & gi|| 57345467 \\
\hline 2 & Hypothetical protein & Vitis vinifera & $64 / 6$ & $39.6 / 6.3$ & gi|| 157356650 \\
\hline 3 & $\begin{array}{l}\text { Alanine aminotransferase-like } \\
\text { protein }\end{array}$ & Arabidopsis thaliana & $388 / 11$ & $39.5 / 5.56$ & gi|| 4596229 \\
\hline 4 & $\begin{array}{l}\text { Fructose } 1,6, \text { bisphosphate } \\
\text { aldolase }\end{array}$ & Salicornia herbacea & $66 / 4$ & $38.0 / 5.7$ & gi|40362980 \\
\hline \multicolumn{6}{|l|}{ Block D } \\
\hline 1 & Putative glycine rich protein & Rumex obtusifolius & $66 / 3$ & $28.8 / 5.2$ & gi| 20152613 \\
\hline 2 & $\begin{array}{l}\text { Peroxiredoxin Chain A, } \\
\text { Prx D (Type li) }\end{array}$ & Populus tremula & $244 / 6$ & $27.2 / 5.25$ & gi|66360|7| \\
\hline 3 & Carbonic anhydrase isoform 2 & Gossypium hirsutum & $231 / 5$ & $26.5 / 5.5$ & gi|47549I5 \\
\hline 4 & Hypothetical protein & Vitis vinifera & $145 / 15$ & $25.3 / 5.7$ & gi| 157356650 \\
\hline 5 & ATP synthase epsilon subunit & Vitis vinifera & $446 / 12$ & $37.9 / 5.7$ & gi|22797822 \\
\hline \multicolumn{6}{|l|}{ Block E } \\
\hline 1 & $\begin{array}{l}\text { Putative formate- } \\
\text { tetrahydrofolate ligase }\end{array}$ & Oryza sativa (japonica) & $68 / 4$ & $23.6 / 5.4$ & gi|5।536।02 \\
\hline \multicolumn{6}{|l|}{ Block F } \\
\hline 1 & $\begin{array}{l}\text { Rieske } \mathrm{Fe} / \mathrm{S} \text { protein of } \\
\text { cytochrome b6/f complex }\end{array}$ & Nicotiana tabacum & $244 / 6$ & $16.2 / 6.5$ & gi|| 19999 \\
\hline 2 & Peroxiredoxin & Phaseolus vulgaris & $285 / 4$ & $15.5 / 6.6$ & gi||II558242 \\
\hline \multicolumn{6}{|c|}{ Block G } \\
\hline 1 & Rubisco large subunit & Tetrastigma hookeri & $286 / 7$ & 19.0/6.7 & gi| 6973388 \\
\hline 2 & IgE-binding protein MnSOD & Hevea brasiliensis & $57 / 3$ & $20.2 / 6.1$ & gi|| $08628 \mid 8$ \\
\hline 3 & Hypothetical protein & Arabidopsis thaliana & $61 / 10$ & $22.7 / 6.24$ & gi| I 5233454 \\
\hline 4 & $\begin{array}{l}\text { Ribulose bisphosphate } \\
\text { carboxylase small chain } \\
\text { chloroplast precursor }\end{array}$ & Pyrus pyrifolia & $83 / 8$ & $20.6 / 6.42$ & gi|| $32 \mid 53$ \\
\hline \multicolumn{6}{|l|}{ Block H } \\
\hline I & Hypothetical protein & Arabidopsis thaliana & $160 / 7$ & $58.3 / 7.6$ & gi| 15240804 \\
\hline 2 & Hypothetical protein & Vitis vinifera & $190 / 6$ & $55.5 / 7.75$ & gi|| 57354496 \\
\hline 3 & Hypothetical protein & Vitis vinifera & $279 / 14$ & $52.1 / 7.7$ & gi| 157337667 \\
\hline \multicolumn{6}{|l|}{ Block I } \\
\hline 1 & $\begin{array}{l}\text { Superoxide dismutase } \\
\text { [Cu-Zn], chloroplast }\end{array}$ & Pinus sylvestris & $245 / 4$ & $48 / 6.78$ & gi|| 34685 \\
\hline 2 & Photosystem II protein 33kD & Spinacia oleracea & $426 / 6$ & $47.3 / 6.9$ & gi|2249I6 \\
\hline 3 & 4-nitrophenylphosphatase-like & Arabidopsis thaliana & $144 / 9$ & $46.5 / 6.8$ & gi|8953699 \\
\hline
\end{tabular}


Table 2 (Continued)

\begin{tabular}{|c|c|c|c|c|c|}
\hline Spot \# & Protein name & Taxonomy & $\begin{array}{l}\text { Mascot scorel } \\
\text { peptides matched }\end{array}$ & $\begin{array}{l}\text { Theoretical } \\
\text { mass }(k D a) / p l\end{array}$ & $\begin{array}{l}\text { Accession } \\
\text { number }\end{array}$ \\
\hline \multicolumn{6}{|l|}{ Block J } \\
\hline 1 & Rubisco large subunit & Tetrastigma hookeri & $286 / 7$ & $29 / 7.23$ & gi| 16973388 \\
\hline 2 & Rubisco large subunit & $\begin{array}{l}\text { Parthenocissus } \\
\text { himalayana }\end{array}$ & $74 / 7$ & $45.8 / 7$ & gi| 16973408 \\
\hline 3 & Hydroxypyruvate reductase & Bruguiera gymnorrhiza & $105 / 6$ & $45.6 / 7.32$ & gi| | 3873334 \\
\hline 4 & $\begin{array}{l}\text { Sedoheptulose-I, } \\
\text { 7-bisphosphate, chloroplast } \\
\text { precursor }\end{array}$ & Spinacia oleracea & $156 / 10$ & $43.9 / 7.43$ & gi|39|4940 \\
\hline \multicolumn{6}{|l|}{ Block K } \\
\hline 1 & Phytocalpain & $\begin{array}{l}\text { Nicotiana } \\
\text { benthamiana }\end{array}$ & $62 / 10$ & $25.8 / 6.95$ & gi|3849065 I \\
\hline \multicolumn{6}{|l|}{ Block L } \\
\hline 1 & $\begin{array}{l}\text { Elongation factor } \mathrm{G} \text {, } \\
\text { chloroplast precursor }\end{array}$ & Glycine max & $402 / 16$ & 31.517 .4 & gi|461999 \\
\hline 2 & $\begin{array}{l}\text { Elongation factor G, } \\
\text { chloroplast precursor }\end{array}$ & Glycine max & $402 / 16$ & $31.5 / 7.5$ & gi|461999 \\
\hline 3 & Putative glycine rich protein & Rumex obtusifolius & $66 / 3$ & $28 / 7.6$ & gi|20152613 \\
\hline 4 & Hypothetical protein & Vitis vinifera & $238 / 17$ & $23.1 / 7.65$ & gi| 157356650 \\
\hline 5 & P 23 Protein & Solanum tuberosum & $136 / 3$ & $20.2 / 7.69$ & gi|587546 \\
\hline
\end{tabular}

that combine ATP synthesis and hydrolysis with the transport of protons across a membrane. Other identified proteins include $\mathrm{RuBisCO}$ activase, which catalyses the reactivation of $\mathrm{RuBisCO}$ in the presence of RuBP or other inhibitory sugar phosphates. ${ }^{37}$ Ribulose 1,5-bisphosphate carboxylase/ oxygenase $(\mathrm{RuBisCO})$ is the key regulatory enzyme responsible for $\mathrm{CO}_{2}$ fixation during photosynthesis. It is localized in the chloroplast stroma and is composed of eight small subunits encoded by a small nuclear multigene family, and eight large subunits encoded by a single gene in the multicopy chloroplast genome. The enzyme glutamine synthetase (GS; E.C. 6.3.1.2) plays central role in nitrogen metabolism and has diverse metabolic and developmental regulation in different plant species and organs. ${ }^{38}$ Two major isoforms exist for the GS enzyme: cytosolic GS, occurring in the cytoplasm of leaves and nonphotosynthetic organs, and chloroplastic GS, present only in the chloroplasts of photosynthetic tissues and the plastids of roots or etiolated plants. The relative proportions of the cytosolic and plastidial GS activity may vary within different organs of the same plant or within different plant species depending on their photosynthetic type. ${ }^{39}$ The $33 \mathrm{kDa}$ protein with pI 5.2 found in muscadine leaf is homologous to oxygen evolving enhancer protein 1 (OEE1). Oxygen evolving enhancer protein (OEE) consist of three subunits, OEE 1 (33 kDa), OEE 2 (23 kDa), and OEE 3 (16 kDa). These are nuclear-encoded chloroplast proteins, and peripherally bound to photosystem II on the luminal side of the thylakoid membrane. ${ }^{40}$ Dehydrogenases (GAPDHs) of higher plants are marker proteins for important aspects of chloroplast evolution and biogenesis. Although descendants of a common phylogenetic ancestor, ${ }^{41,42}$ they differ in several structural features. The Cytosolic NADspecific dehydrogenase is a single homotetramer like the corresponding enzymes from other sources. Chloroplast NADP-dependent dehydrogenase is composed of two major isoenzymes $\mathrm{A} 2 \mathrm{~B} 2$ and $\mathrm{A} 4$; subunits $\mathrm{A}$ and $\mathrm{B}$ are distinguished by slightly different molecular weights. ${ }^{43}$ Glyoxysomes are unique to plant cells and house in addition to the enzymes for 3-oxidation of fatty acids, the glyoxylate cycle, a variant of the tricarboxylic acid cycle. Superoxide oxidoreductase (EC 1.15.1.1) catalyze the dismutation of superoxide to dioxygen and hydrogen peroxide to protect organisms from oxidative damage. ${ }^{44}$ Superoxide oxidoreductases (SODs) are metalloproteins that are classified into three types (Mn-, Fe-, and $\mathrm{Cu} / \mathrm{Zn}-\mathrm{SOD}$ ) depending on the metal found in the active site. In plants, the most prominent SODs are $\mathrm{Cu} / \mathrm{Zn}$ isozymes. It has been shown that transgenic plants that overexpress chloroplastic $\mathrm{Cu} / \mathrm{Zn}-\mathrm{SOD}$ increase resistance to oxidative stress ${ }^{45}$ and the activity of plant SOD increases in response to a variety of environmental and chemical stimuli. ${ }^{46}$ Recently, increased levels of SOD activities resulting from differential regulation of individual SOD genes at the transcriptional leve1 were also reported. ${ }^{47}$ 
Although no significant differences were observed in major leaf proteins, quantitative variations were found in several proteins among muscadine cultivars. Of the 217 proteins identified, 39 proteins were found to be differentially expressed among muscadine genotypes, out of which eight are with unknown function. Further investigation using leaf tissue from a larger number of muscadine genotypes, different leaf and berry developmental stages, during veraison and healthy and infected tissue will provide better insight into the function of known and unknown proteins of muscadine leaf that affect plant development, berry composition, and its enological value.

\section{Acknowledgments}

This research was supported by grants from the Florida Department of Agriculture/Viticulture Advisory Council and the USDA/CSREES/CBG. We wish to thank Dr Tibor Pechan, Mississippi State University for LC/MS analysis. The authors report no conflicts of interest in this work.

\section{References}

1. Kingston-Smith AH. Resource allocation. Trends Plant Sci. 2001;6: 48-49.

2. Swanson CA, Elshishiny EDH. Translocation of sugars in the Concord grape. Plant Physiol. 1958;33:33-37.

3. Boss PK, Davies C. Molecular biology of sugar and anthocyanin accumulation in grape berries. In: Roubelakis-Angelakis KA, editors. Molecular Biology and Biotechnology of the Grapevine. Dordrecht, The Netherlands: Kluwer Academic Publishers; 2001. p. 1-33.

4. Castro AJ, Carapito C, Zorn N, et al. Proteomic analysis of grapevine (Vitis vinifera L.) tissues subjected to herbicide stress. J Exp Bot. 2005;56:2783-2795.

5. Jones AME, Thomas V, Truman W, Lilley K, Mansfield J, Grant M. Specific changes in the Arabidopsis proteome in response to bacterial challenge: differentiating basal and R-gene mediated resistance. Phytochemistry. 2004;65:1805-1816.

6. Rakwal R, Komatsu S. Role of jasmonate in the rice (Oryza sativa L.) self-defense mechanism using proteome analysis. Electrophoresis. 2000;21:2492-2500.

7. Schlesier B, Berna A, Bernier, F, Mock HP. Proteome analysis differentiates between two highly homologues germin-like proteins in Arabidopsis thaliana ecotypes Col-0 and Ws-2. Phytochemistry. 2004;65:1565-1574.

8. Wilson KA, McManus MT, Gordon ME, Jordan TW. The proteomics of senescence in white clover Trifolium repens leaves. Proteomics. 2002;2:1114-1122.

9. Rose JK, Bashir S, Giovannoni JJ, Jahn MM, Saravanan RS. Tackling the plant proteome: practical approaches, hurdles and experimental tools. Plant J. 2004;39:715-733.

10. Koller A, Washburn MP, Lange BM, et al. Proteomic survey of metabolic pathways in rice. Proc Natl Acad Sci US A. 2002;18:11969-11974.

11. Giavalisco P, Nordhoff E, Kreitler T, et al. Proteome analysis of Arabidopsis thaliana by two-dimensional gel electrophoresis and matrix-assisted laser desorption/ionisation-time of flight mass spectrometry. Proteomics. 2005;5:1902-1913.

12. Porubleva L, Vander Velden K, Kothari S, Oliver DO, Parag R, Chitnis PR. The proteome of maize leaves: Use of gene sequences and expressed sequence tag data for identification of proteins with peptide mass fingerprints. Electrophoresis. 2001;22:1724-1738.
13. Donelly BE, Madden RD, Ayoubi P, Porter DR, Dillwith JW. The wheat (Triticum aestivum L.) leaf proteome. Proteomics. 2005;5: 1624-1633.

14. Bahrman N, Le Gouis J, Negroni L, et al. Differential protein expression assessed by two-dimensional gel electrophoresis for two wheat varieties grown at four nitrogen levels. Proteomics. 2004;4:709-719.

15. Schiltz S, Gallardo K, Huart M, Negroni L, Sommerer N, Burstin J. Proteome reference maps of vegetative tissues in pea. An investigation of nitrogen mobilization from leaves during seed filling. Plant Physiol. 2004; 135:2241-2260.

16. Negri AS, Prinsi B, Rossoni M, et al. Proteome changes in the skin of the grape cultivar Barbera among different stages of ripening. $B M C$ Genomics. 2008;9:378-397.

17. Sarry JE, Sommerer N, Sauvage FX, et al. Grape berry biochemistry revisited upon proteomic analysis of the mesocarp. Proteomics. 2004;4:201-215.

18. Deytieux C, Geny L, Lapaillerie D, et al. Proteome analysis of grape skins during ripening. J Exp Bot. 2007;58:1851-1862.

19. Negri AS, Prinsi B, Scienza A, Morgutti S, Cocucci M, Espen L. Analysis of grape berry cell wall proteome: a comparative evaluation of extraction methods. J Plant Physiol. 2008;165:1379-1389.

20. Giribaldi M, Perugini I, Sauvage FX, Schubert A. Analysis of protein changes during grape berry ripening by 2-DE and MALDI-TOF. Proteomics. 2007; 7:3154-3170.

21. Jellouli N, Ben JH, Skouri H, Ghorbel A, Gourgouri A, Mliki A. Proteomic analysis of Tunisian grapevine cultivar Razegui under salt stress. J Plant Physiol. 2008;165:471-481.

22. Sauvage FX, Pradal M, Chatelet P, Tesniere C. Proteome changes in leaves from grapevine (Vitis vinifera L.) transformed for alcohol dehydrogenase activity. J Agric Food Chem. 2007;55:2597-2603.

23. Vincent D, Ergul A, Bohlman MC, et al. Proteomic analysis reveals differences between Vitis vinifera L. cv. Chardonnay and cv. Cabernet Sauvignon and their responses to water deficit and salinity. J Exp Bot. 2007;58:1873-1892.

24. Bradford MM. A rapid and sensitive method for the quantitation of microgram quantities of protein utilizing the principle of protein-dye binding. Anal Biochem. 1976;72:248-254.

25. Basha SM. Identification of cultivar differences in seed polypeptide composition of peanuts (Arachis hypogaea L.) by two-dimensional polyacrylamide gel electrophoresis. Plant Physiol. 1979;63:301-306.

26. Mujahid S, Pechan T, Wang C. Improved solubilization of surface proteins from Listeria monocytogenes for 2-DE. Electrophoresis. 2007;28:3998-4007.

27. Perkins DN, Pappin DJ, Creasy DM, Cottrell JS. Probability-based protein identification by searching sequence databases using mass spectrometry data. Electrophoresis. 1999;20:3551-3567.

28. Altschul SF, Madden TL, Schaffer AA, et al. Gapped BLAST and PSI-BLAST: a new generation of protein database search programs. Nucleic Acids Res. 1997;25:3389-3402.

29. Basha SM, Roberts RM. The glycoproteins of plant seeds: Analysis by two-dimensional polyacrylamide gel electrophoresis and by their lectin-binding properties. Plant Physiol. 1981;67:936-939.

30. Shen S, Yuxiang J, Kuang T. Proteomics approach to identify wound-response related proteins from rice leaf sheath. Proteomics. 2003;3:527-535.

31. Ferri M, Tassoni A, Franceschetti M, et al. Chitosan treatment induces changes of protein expression profile and stilbene distribution in Vitis vinifera cell suspensions. Proteomics. 2009;9:1-15.

32. Marmagne A, Rouet MA, Ferro M, et al. Identification of new intrinsic proteins in Arabidopsis plasma membrane proteome. Mol Cell Proteomics. 2004;3:675-691.

33. Komatsu S, Konishi H, Hashimoto M. The proteomics of plant cell membranes. J Exp Bot. 2007;58:103-112.

34. Boorstein WR, Ziegelhoffer T, Craig EA. Molecular evolution of the HSP70 multigene family. J Mol Evol. 1994;38:1-17.

35. Hartl FU. Molecular chaperones in cellular protein folding. Nature. 1996;381:571-580. 
36. Rüdiger S, Buchberger A, Bukau B. Interaction of Hsp70 chaperones with 4 substrates. Nature Struct Biol. 1997;4:342-349.

37. Portis AR Jr. Rubisco activase. Biochim Biophys Acta. 1990;1015:15-28.

38. Cren M, Hirel B. Glutamine synthetase in higher plants: regulation of gene and protein expression from the organ to the cell. Plant Cell Physiol. 1999;40:1187-1193.

39. McNally SF, Hirel B, Gadal P, Mann AF, Stewart GR. Glutamine synthetase in higher plants: evidence for a specific isoform content related to their possible physiological role and their compartmentation within the leaf. Plant Physiol. 1983;72:22-25.

40. Robinson C, Klösgen RB. Targeting of proteins into and across the thylakoid membrane: a multitude of mechanisms. Plant Mol Biol. 1994;26:15-24.

41. Cerff R, Chambers SE. Subunit structure of higher plant glyceraldehyde3-phosphate dehydrogenases. J Biol Chem. 1979;254:6094-6098.
42. Cornish-Bowden A. Critical values for testing the significance of amino acid composition indexes. Anal Biochem. 1980;105:233-238.

43. Cerff R. Quaternary structure of higher plant glyceraldehyde3-phosphate dehydrogenases. Eur J Biochem. 1979;94:243-247.

44. Hassan HM. Determination of microbial damage caused by oxygen free radicals, and the protective role of superoxide dismutase. Methods Enzymol. 1984;105:405-412.

45. Gupta AS, Heinen JL, Holaday AS, Burke JJ, Allen RD. Increased resistance to oxidative stress in transgenic plants that overexpress chloroplastic Cu/Zn superoxide dismutase. Proc Natl Acad Sci U S A. 1993;90:1629-1933.

46. Fridovich I. Superoxide dismutases. Adv Enzymol. 1986;58:61-97.

47. Perl-Treves R, Galun E. The tomato $\mathrm{Cu} / \mathrm{Zn}$ superoxide dismutase genes are developmentally regulated and respond to light and stress. Plant Mol Biol. 1991;17:745-760.
International Journal of Wine Research

\section{Publish your work in this journal}

The International Journal of Wine Research is an international, peer-reviewed open-access, online journal focusing on all scientific aspects of wine, including: vine growing; wine elaboration; human interaction with wine; and health aspects of wine. The journal provides an open access platform for the reporting

\section{Dovepress}

of evidence based studies on these topics. The manuscript management system is completely online and includes a very quick and fair peer-review system, which is all easy to use. Visit http://www.dovepress.com/testimonials.php to read real quotes from some of our published authors.

Submit your manuscript here: http://www.dovepress.com/international-journal-of-wine-research-journalisease-journal 